\title{
可回收铜纳米颗粒在无溶剂下催化三组分偶联反应合成炔丙基胺
}

\author{
史大鹏 ${ }^{a}$ 段中余*,a,b \\ ( ${ }^{a}$ 河北工业大学化工学院 天津 300130) \\ ( ${ }^{b}$ 河北工业大学天津市本质安全化工技术重点实验室 天津 300130)
}

\begin{abstract}
摘要 以硫酸铜为原料, 水合肼为还原剂, 采用水热法合成了铜纳米粒子. 用透射电子显微镜(TEM)和 $\mathrm{X}$ 射线衍射 (XRD)对所得催化剂进行了表征, 继而成功地将其用作非均相催化剂, 促进了苯乙炔、胺和醛在无溶剂条件下的三组分 偶联反应. 在 $\mathrm{Cu} N \mathrm{Ns}(10 \mathrm{~mol} \%) 、 110{ }^{\circ} \mathrm{C} 、 10 \mathrm{~h}$ 反应条件下，催化剂表现出良好的催化活性，产率达 $88 \%$. 值得注意的 是, 经过 4 次循环使用后, 催化剂体系的催化活性仅略有下降(分离产率 $>84 \%$ ). 本研究结果提供了一种三组分偶联反 应合成丙㶧胺的方法，该方法具有后处理简单、无溶剂、底物范围广、催化剂可重复使用等优点.
\end{abstract}

关键词＼cjkstart铜纳米粒子; 炔丙基胺; 三组分偶联; 无溶剂; 可回收性

\section{Propargylamine Synthesis via Three-Component Coupling Reaction Catalyzed by Recyclable Cu Nanoparticles under Solvent-Free Conditions}

\author{
Shi, Dapeng ${ }^{a} \quad$ Duan, Zhongyu ${ }^{*, a, b}$ \\ ( ${ }^{a}$ School of Chemical Engineering and Technology, Hebei University of Technology, Tianjin 300130) \\ ( ${ }^{b}$ Tianjin Key Laboratory of Chemical Process Safety, Hebei University of Technology, Tianjin 300130)
}

\begin{abstract}
In this paper, copper nanoparticles (Cu NPs) were synthesized from copper sulfate by hydrothermal method using hydrazine hydrate as reducing agent. The obtained catalyst was characterized by transmission electron microscope (TEM) and $\mathrm{X}$-ray diffraction (XRD), and successfully used as heterogeneous catalyst to promote the three-component coupling reaction of phenylacetylene, amine and aldehyde in solvent-free. Under $\mathrm{Cu} N P s(10 \mathrm{~mol} \%), 110{ }^{\circ} \mathrm{C}$ and reaction time $10 \mathrm{~h}$, the catalyst exhibits excellent catalytic activity with $88 \%$ yield. It is worth noting that the catalyst system can maintain high catalytic activity with only a slight decrease after 4 cycles (all isolated yields $>84 \%$ ). A propargylamine synthetic method by three-component coupling reaction was provided possessing the advantages of simple post-treatment procedure, solvent-free, extensive substrate range and good reusability of catalyst.

Keywords copper nanoparticles; propargylamine; three-component coupling; solvent-free; recyclability
\end{abstract}

\section{Introduction}

Metal-catalyzed multi-component reaction (MC-MCR) is a powerful method for synthesizing many complex products from simple precursors, which has a wide impact on the development of organic synthesis, biochemistry, materials science, and medicinal chemistry. ${ }^{[1 \sim 4]}$ The related literature reports that transition metal catalyzed threecomponent coupling among aldehydes, alkynes and amines (commonly referred to as $\mathrm{A}^{3}$-coupling) is a convenient and versatile route for the preparation of propargylamines. ${ }^{[5,6]}$ In general, the $\mathrm{A}^{3}$-coupling reaction is catalyzed by a tran- sition metal via $\mathrm{C}-\mathrm{H}$ activation. For example, the use of various catalysts such as $\mathrm{Cu},{ }^{[7 \sim 10]} \mathrm{Ag},{ }^{[11 \sim 13]} \mathrm{In},{ }^{[14,15]} \mathrm{Bi},{ }^{[16]}$ $\mathrm{Ni}^{[17,18]} \mathrm{Fe},^{[19,20]} \mathrm{Pd}^{[21]}$ and Au-based ${ }^{[22,23]}$ catalysts under different reaction conditions including solvent-free, conventional heating methods and ionic liquid have been reported. However, some of these methods require expensive metal catalysts $(\mathrm{Ag}, \mathrm{Au}, \mathrm{Pd}$, etc. $)$, some catalysts are not easily available, some use harmful solvents, and some catalysts have poor cycle performance. Hence, developing efficient and hetero catalysts for the green synthesis of propargylamines is of great significance. ${ }^{[24 \sim 26]}$ In addition,

* Corresponding author. E-mail: zyduan@hebut.edu.cn

Received December 3, 2019; revised January 9, 2020; published online January 21, 2020

Project supported by the National Natural Science Foundation of China (No. 51473045).

国家自然科学基金(No. 51473045)资助项目. 
the excellent catalytic efficiency, low cost and low toxicity of copper nanoparticles make it a hot research topic in organic synthesis. It is found that transition metal copper catalysts have a good catalytic effect on the $\mathrm{A}^{3}$-coupling reaction compared to other metals in many published literatures. ${ }^{[10,27,28]}$ Based on our previous work, ${ }^{[29]}$ copper nanoparticles ( $\mathrm{Cu}$ NPs) were prepared by hydrothermal method and characterized. Furthermore, we report the efficient propargylamine synthesis via three-component coupling reaction catalyzed by the copper nanoparticles (Scheme 1).

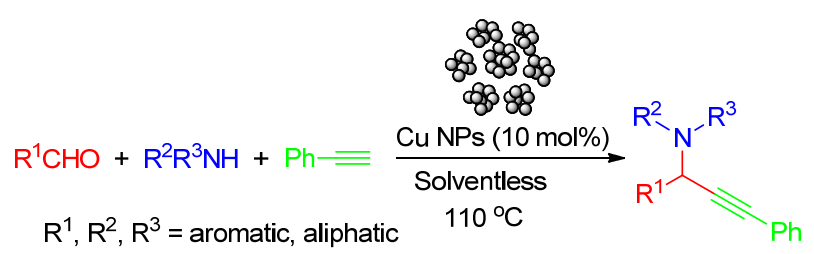

Scheme $1 \mathrm{Cu}(\mathrm{NPs})$ catalyzed $\mathrm{A}^{3}$-coupling reaction to form propargylamine.

\section{Results and discussion}

$\mathrm{Cu}$ NPs were synthesized by hydrothermal method using sodium dodecylbenzene sulfonate (DBS) as surfactant and hydrazine hydrate as reducing agent. ${ }^{[29]}$

The surface morphology and particle size of the copper nanoparticles were determined using transmission electron microscope (TEM). The TEM image shows a relatively uniform dispersion of nanoparticles, in which each big spherical (about $90 \mathrm{~nm}$ ) is composed with a lot of little particles (Figure 1). The size and shape of these nanoparticles are moderately uniform and dispersed well, no observing obvious agglomeration.
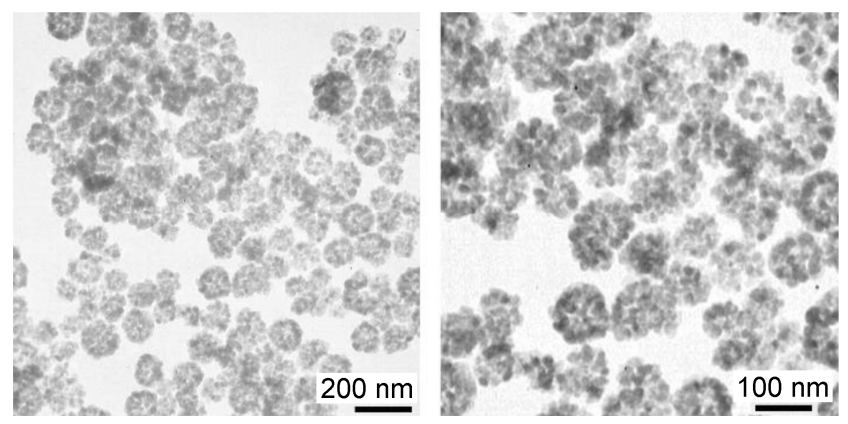

Figure 1 TEM images of $\mathrm{Cu}$ NPs

The powder X-ray diffraction (XRD) pattern of $\mathrm{Cu}$ NPs is shown in Figure 2. Figure 2a shows the XRD pattern of fresh copper nanoparticles. The diffraction peaks observed at $2 \theta=43.29^{\circ}, 50.47^{\circ}$ and $74.13^{\circ}$ correspond to (111), (200) and (220). The peaks in our samples follow the peaks in the standard material (JCPDS file number 04-0836). No diffraction peaks of impurities such as $\mathrm{Cu}_{2} \mathrm{O}$ and other secondary phases were detected. It is clearly observed that the reflection peak is sharp and narrow, indicating the high degree of crystallinity and phase purity of the product. After one use, the XRD curve of the catalyst is shown in Fig- ure 2b. A new small peak appears at $2 \theta=36.49^{\circ}$, which is attributable to the partial oxidation of copper nanoparticles. ${ }^{[30]}$ This can also explain a slight decrease in the yield of propargylamine derivatives in recyclable experiments.

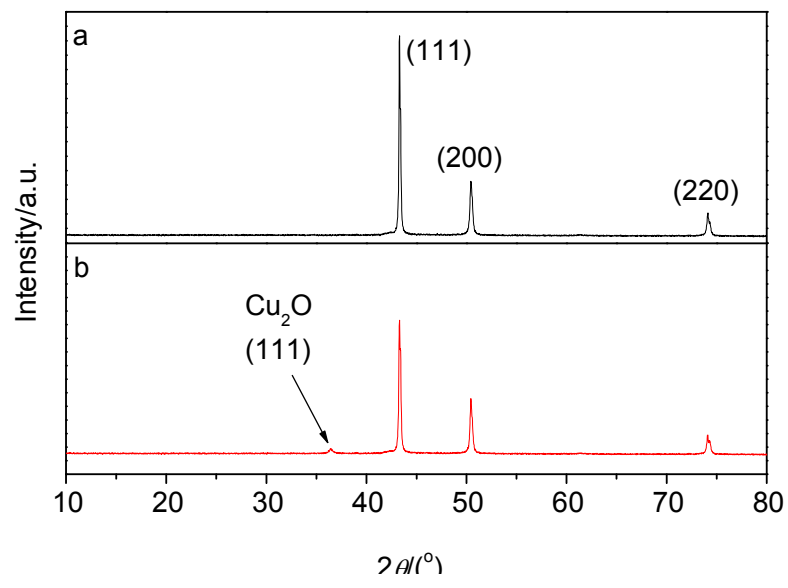

Figure 2 XRD patterns of $\mathrm{Cu}$ NPs

(a) Fresh $\mathrm{Cu}$ NPs; (b) reused Cu NPs

To identify an effective catalyst system and optimum reaction conditions, the model reaction of benzaldehyde, morpholine (1.2 equiv.) and phenylacetylene (1.5 equiv.) was carried out under different reaction conditions. The selected results from our screening experiments are summarized in Table 1.

The $\mathrm{A}^{3}$-coupling reactions were first executed in the absence or presence of different copper sourse catalysts at $110{ }^{\circ} \mathrm{C}$ for $10 \mathrm{~h}$. Our studies showed that copper salt and $\mathrm{Cu}$ NPs can catalyze the model reaction in the different degree (Table 1, Entries 1 6), whereas without added copper source the reaction has been proven ineffective, no affording the desired product even after $72 \mathrm{~h}$ (Table 1, Entry 2). Cu NPs displayed the best catalytic effect (isolated yield of $88 \%$ ) in several copper sources tested in this paper (Table 1, Entry 1). Such a low yield in the copper salt catalysis could be due to decomposition because of intense heat evolution upon mixing the substrates under solvent-free conditions. ${ }^{[31]}$ The loading scale of the $\mathrm{Cu}$ NPs catalyst (Table 1, Entries 7 10), the impact of reaction temperature (Table 1, Entries 11 and 15) and reaction time (Table 1, Entries 16 19) on this reaction were also assessed. Furthermore, the reactions with different solvents (PhMe, $\mathrm{H}_{2} \mathrm{O}, \mathrm{CH}_{2} \mathrm{Cl}_{2}$, EtOH, $\mathrm{MeOH}$, THF) occurred without or with less to medium quantity products (Table 1, Entries 20 25). Notably, the treatment of benzaldehyde, morpholine (1.2 equiv.) and phenylacetylene (1.5 equiv.) in the $\mathrm{Cu}$ NPs catalyst $(10 \mathrm{~mol} \%)$ at $110{ }^{\circ} \mathrm{C}$ for $10 \mathrm{~h}$ led to the desired propargylamine in $88 \%$ yield under solvent-free conditions (Table 1, Entry 1). It should be noted that the reaction was executed much smoothly in argon atmosphere than in air atmosphere (Table 1, Entries 1 and 14).

Reusability is an important factor in the heterogeneous catalyst effectiveness. To investigate the recycling of the $\mathrm{Cu}$ NPs catalyst, the reusability of the catalyst was deter- 
Table 1 Optimisation trials for the $\mathrm{A}^{3}$-coupling reaction ${ }^{a}$

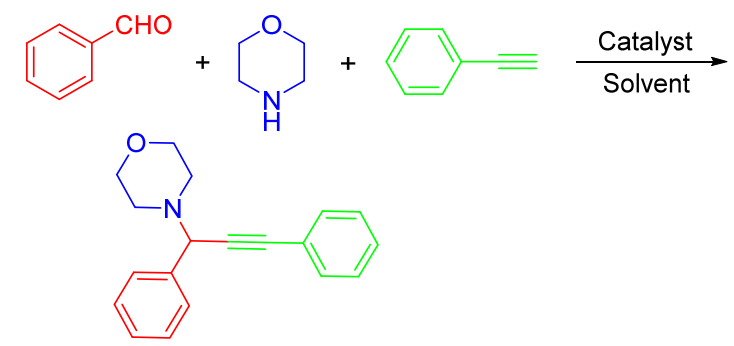

\begin{tabular}{|c|c|c|c|c|c|}
\hline Entry & Catalyst (mol\%) & $T /{ }^{\circ} \mathrm{C}$ & Time/h & Solvent & yield $^{b} / \%$ \\
\hline 1 & $\mathrm{Cu}$ NPs (10) & 110 & 10 & - & 88 \\
\hline 2 & - & 110 & $10(72)$ & - & $\mathrm{NP}^{c}$ \\
\hline 3 & $\mathrm{CuI}(10)$ & 110 & 10 & - & 78 \\
\hline 4 & $\mathrm{CuCl}_{2} \cdot 2 \mathrm{H}_{2} \mathrm{O}(10)$ & 110 & 10 & - & 72 \\
\hline 5 & $\mathrm{Cu}(\mathrm{OAc})_{2} \cdot \mathrm{H}_{2} \mathrm{O}(10)$ & 110 & 10 & - & 57 \\
\hline 6 & $\mathrm{CuSO}_{4} \cdot 5 \mathrm{H}_{2} \mathrm{O}(10)$ & 110 & 10 & - & 46 \\
\hline 7 & $\mathrm{Cu}$ NPs (5) & 110 & 10 & - & 84 \\
\hline 8 & $\mathrm{Cu}$ NPs (8) & 110 & 10 & - & 83 \\
\hline 9 & $\mathrm{Cu}$ NPs (15) & 110 & 10 & - & 87 \\
\hline 10 & $\mathrm{Cu}$ NPs (20) & 110 & 10 & - & 89 \\
\hline 11 & $\mathrm{Cu}$ NPs (10) & 25 & 72 & - & $\mathrm{NP}^{c}$ \\
\hline 12 & $\mathrm{Cu}$ NPs (10) & 90 & 10 & - & 65 \\
\hline 13 & $\mathrm{Cu}$ NPs (10) & 100 & 10 & - & 85 \\
\hline $14^{d}$ & $\mathrm{Cu}$ NPs (10) & 110 & 10 & - & 71 \\
\hline 15 & $\mathrm{Cu}$ NPs (10) & 130 & 10 & - & 84 \\
\hline 16 & $\mathrm{Cu}$ NPs (10) & 110 & 3 & - & 75 \\
\hline 17 & $\mathrm{Cu}$ NPs (10) & 110 & 6 & - & 81 \\
\hline 18 & $\mathrm{Cu}$ NPs (10) & 110 & 12 & - & 88 \\
\hline 19 & $\mathrm{Cu}$ NPs (10) & 110 & 15 & - & 85 \\
\hline 20 & $\mathrm{Cu}$ NPs (10) & Reflux & 10 & $\mathrm{PhMe}$ & 52 \\
\hline 21 & $\mathrm{Cu}$ NPs (10) & Reflux & 10 & $\mathrm{H}_{2} \mathrm{O}$ & $\mathrm{NP}^{c}$ \\
\hline 22 & $\mathrm{Cu}$ NPs (10) & Reflux & 10 & $\mathrm{CH}_{2} \mathrm{Cl}_{2}$ & $\mathrm{NP}^{c}$ \\
\hline 23 & $\mathrm{Cu}$ NPs (10) & Reflux & 10 & EtOH & 16 \\
\hline 24 & $\mathrm{Cu}$ NPs (10) & Reflux & 10 & $\mathrm{MeOH}$ & 15 \\
\hline 25 & $\mathrm{Cu}$ NPs (10) & Reflux & 10 & THF & 9 \\
\hline
\end{tabular}

${ }^{a}$ Reaction conditions: $\mathrm{Cu}$ NPs $(10 \mathrm{~mol} \%)$; aldehyde $(1 \mathrm{mmol})$; amine $(1.2$ mmol); alkyne (1.5 mmol), $110{ }^{\circ} \mathrm{C}, 10 \mathrm{~h} .{ }^{b}$ Isolated yield. ${ }^{c}$ No product. ${ }^{d}$ No argon protection.

mined in the reaction of benzaldehyde, morpholine and phenylacetylene under the optimum reaction conditions $\left(110{ }^{\circ} \mathrm{C}, 10 \mathrm{~h}\right)$. After completion of the reaction, the catalyst was removed by filtration. And the $\mathrm{Cu}$ NPs were washed three times with distilled water and ethanol (10 $\mathrm{mL}$ ). It was then dried in vacuum oven at $60{ }^{\circ} \mathrm{C}$ for $5 \mathrm{~h}$. Repeat the same steps for all other loops. It should be noted that the $\mathrm{Cu}$ NPs catalyst was cycled four times and the reaction conversion rate was not significantly reduced. Even after the fourth round of tests, the yield was still above $80 \%$ (Figure 3). These results confirm the practical recyclability of this catalyst and thus confirm its potential role in modern organic synthesis.

In a further set of experiments, a series of aldehydes, amines were evaluated under the optimal conditions, and the results are summarized in Table 2. It can be seen that the range of catalytic systems is wide and many proper-

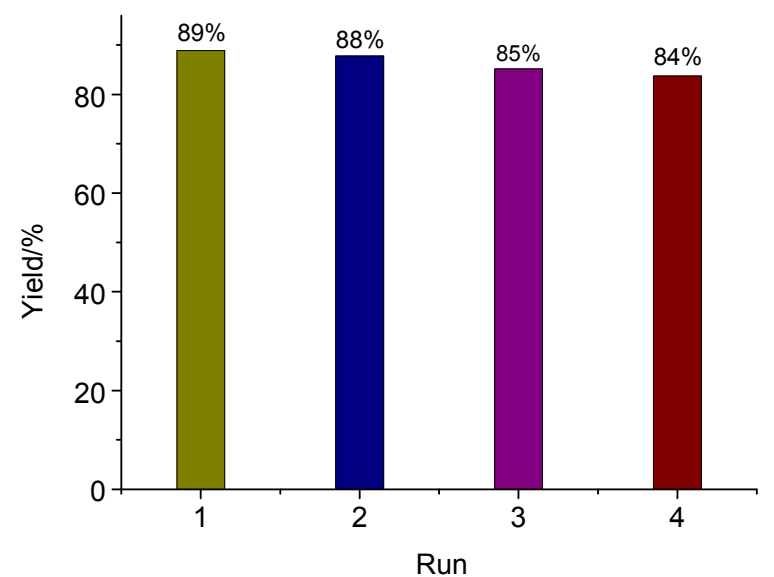

Figure 3 Yields obtained with recycled $\mathrm{Cu}$ NPs catalyst

gylamines have been synthesized in moderate to excellent yields $(49 \% \sim 96 \%, \mathbf{4 a} \sim 4 \mathbf{u})$. Fatty aldehydes such as formaldehyde can provide better yields $(\mathbf{4 d} \sim \mathbf{4 f}, \mathbf{4 t} \sim \mathbf{4 u})$. In addition, for aromatic aldehydes, there was no significant influence of electronic effect on the coupling products, the yield of the aromatic aldehyde with an electron donor $(\mathbf{4 m} \sim \mathbf{4 0})$ and the aromatic aldehyde with an electron withdrawing group $(\mathbf{4 j} \sim \mathbf{4 l}, \mathbf{4 r} \sim \mathbf{4 s})$ is similar. Among them, the aromatic aldehyde containing $\mathrm{OH}$ is not highly reactive in this system, probably because the $p$-hydroxybenzaldehyde is a solid, which causes the reaction to be hindered. After that, solvents $\left(\mathrm{PhMe}, \mathrm{H}_{2} \mathrm{O}, \mathrm{THF}, \mathrm{MeOH}\right)$ were separately added to the system to test the activity of the catalyst $(\mathbf{4 p} \sim \mathbf{4 q})$. It was found that the catalytic effect of the addition of the solvent catalyst was not improved compared with the solventless system. The reaction yield of 2-pyridine formaldehyde was very low. Interestingly, the reaction of 2-thiophenecarboxaldehyde was very good and the corresponding propargylamine was obtained in $84 \%$ yield (4i). The isolated product was completely characterized by ${ }^{1} \mathrm{H}$ NMR.

Based on the experiments and relevant literature, ${ }^{[1,18,32]}$ the proposed mechanism was speculated as showed in Scheme 2. First, the alkyne is activated by $\mathrm{Cu}$ NPs to generate intermediate (3A). After deprotonation, the copper alkyne intermediate (3B) is formed, and then it is coordinated with the imine ion (2A) generated in situ from the aldehyde and the amine to form an activated complex. Finally, a nucleophilic addition reaction between alkynyl-Cu and imine produces the corresponding propargylamine product (4), and the $\mathrm{Cu}$ NPs catalyst also enters the next reaction cycle. During this cycle, $\mathrm{Cu}$ NPs catalysts may be oxidized and deactivated when alkynes are activated, but only a few of them occur.

The efficiency of the $\mathrm{Cu}$ NPs catalyst with the efficiency of some other reported copper catalysts based on the $\mathrm{A}^{3}$-coupling reaction are compared in Table 3. From Table 3 , it is shown that all catalysts display from medium to excellent catalytic effects. Compared with these methods, $\mathrm{Cu}$ NPs reported here have the advantages of lower cost, easier product preparation and separation, and good yield. 
Table 2 A $\mathrm{A}^{3}$-coupling of aldehydes (1), amines (2), and alkynes (3) catalyzed by $\mathrm{Cu}$ NPs catalyst for production of propargylamines (4)

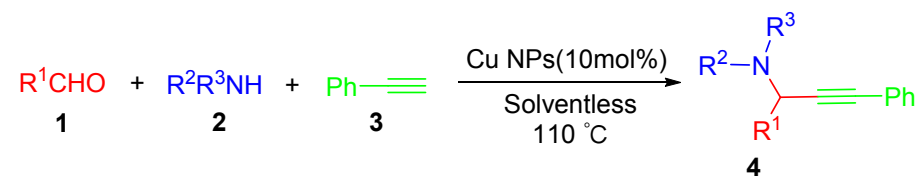<smiles>C(#CC(c1ccccc1)N1CCOCC1)c1ccccc1</smiles>

4a $88 \%$<smiles>CC(C)(C)CC1CCCCN1C#Cc1ccccc1</smiles><smiles>CC1CCN(C(C#Cc2ccccc2)c2ccccc2Cl)CC1</smiles>

4k $90 \%$<smiles>Oc1ccc(C(C#Cc2ccccc2)N2CCOCC2)cc1</smiles>

4p Trace

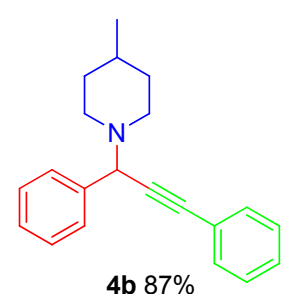

4b $87 \%$<smiles>C(#CC(c1ccccc1)N1CCOCC1)c1cccs1</smiles>

$4 g 67 \%$

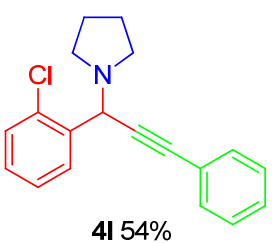

4I $54 \%$<smiles>Oc1cccc(C(C#Cc2ccccc2)N2CCOCC2)c1O</smiles>

4q Trace<smiles>C1COCCN1</smiles>

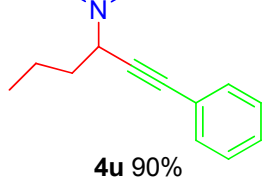

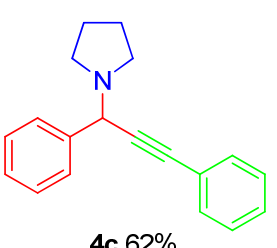

$4 c 62 \%$

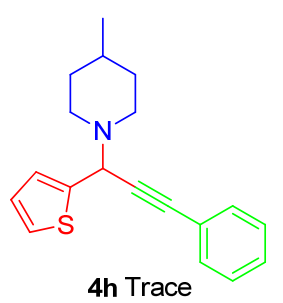<smiles>COc1ccc(C(C#Cc2ccccc2)N2CCOCC2)cc1OC</smiles>

$4 m 73 \%$<smiles>O=[N+]([O-])c1ccc(C(C#Cc2ccccc2)N2CCOCC2)cc1</smiles>

4r $49 \%$

$78 \%$

4d $72 \%$

4i $84 \%$

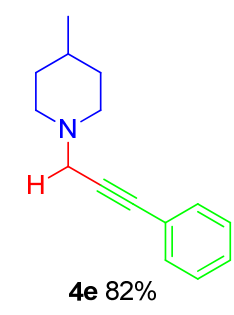<smiles>CC(C)(C)[C@H](C#Cc1ccccc1)c1cccs1</smiles><smiles>COc1ccc(C(C#Cc2ccccc2)N2CCC(C)CC2)cc1OC</smiles><smiles>COc1ccc(C(C#Cc2ccccc2)N2CCCC2)cc1OC</smiles>

4o $87 \%$<smiles>FC(F)(F)c1ccc(C(C#Cc2ccccc2)N2CCOCC2)cc1</smiles><smiles>CCCCC(C#Cc1ccccc1)N1CCOCC1</smiles>

4t $96 \%$

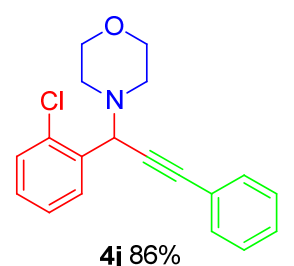

4j $86 \%$

${ }^{a}$ Aldehyde (1) $:$ amine (2) : Phenylacetylene (3) $=1: 1.2: 1.5$ (molar ratio). ${ }^{b}$ Isolated yield.

So metal NPs have broad application prospects in organic catalysis.

\section{Conclusions}

In summary, the prepared $\mathrm{Cu}$ NPs displays a favorable catalytic property for the formation of propargylamine via a three-component coupling under solvent-free conditions. Structurally different propargylamines have been synthesized in moderate to excellent yields $(49 \% \sim 96 \%)$. Compared with the traditional methods, our procedure possesses lower cost, easier products separation, and higher yields.
More importantly, the $\mathrm{Cu}$ NPs can be reused and always remain the catalytic property (four times, $>84 \%$ isolated yield). The process can make a valuable contribution to existing methods in the field of propargylamine synthesis, and further mechanistic investigation is currently in progress.

\section{Experimental section}

Unless otherwise stated, all reactions were carried out without taking precautions to exclude air and moisture. All 


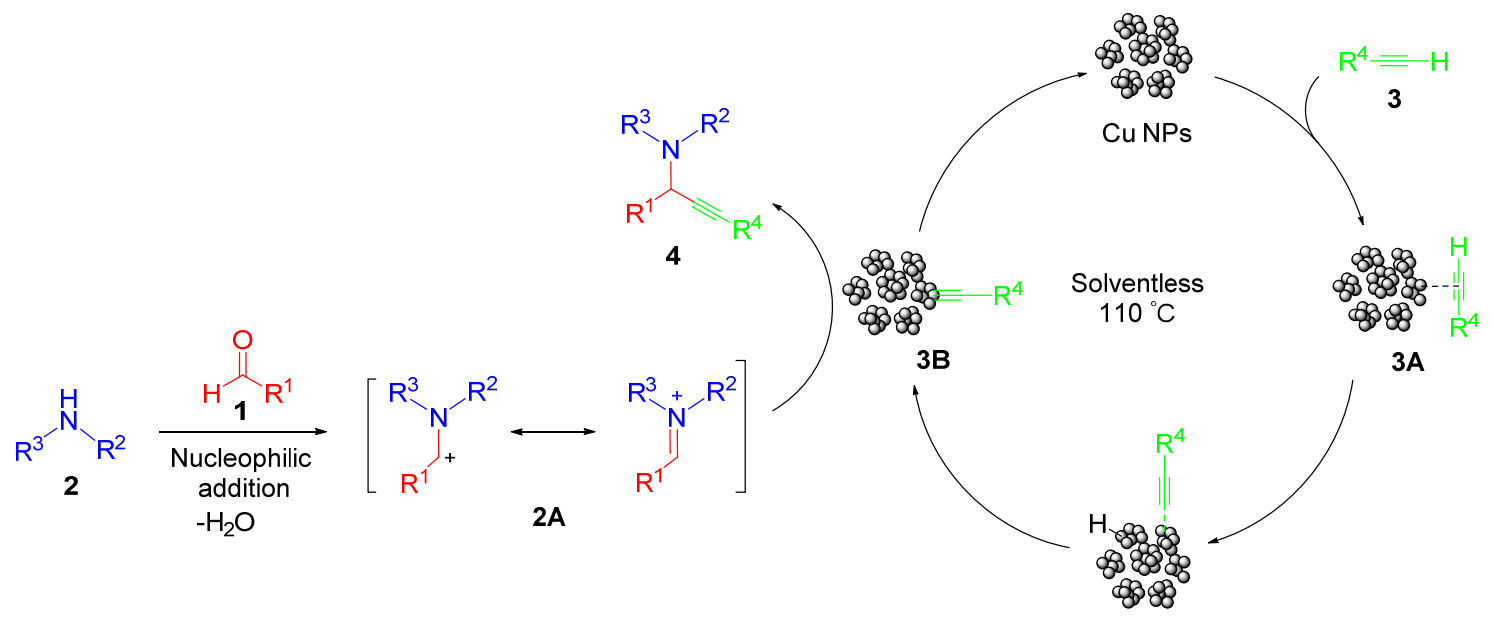

Scheme 2 Proposed mechanism for the three component coupling reaction carried on $\mathrm{Cu}$ NPs

Table 3 Comparison of $\mathrm{Cu}$ NPs with other reported data ${ }^{a}$

\begin{tabular}{|c|c|c|c|c|c|c|}
\hline Entry & Catalyst & Solvent & Time/ & $\mathrm{a} T /{ }^{\circ} \mathrm{C}$ & ield $/ \%$ & Ref. \\
\hline 1 & $\mathrm{CuI}_{2}$ (pip) $)_{2}$ & Toluene & 2 & 110 & 96 & {$[3]$} \\
\hline 2 & $\mathrm{GO}-\mathrm{Cu}$ & $\mathrm{H}_{2} \mathrm{O}$ & 8 & 100 & 83 & [8] \\
\hline 3 & Cu-salen-AAIL & $\mathrm{H}_{2} \mathrm{O}$ & 6 & 100 & 93 & [9] \\
\hline 4 & {$[\mathrm{Cu}(\mathrm{L})] \cdot 0.5 \mathrm{H}_{2} \mathrm{O}$} & Toluene & 7 & 80 & 93 & {$[33]$} \\
\hline 5 & $\mathrm{CMC}-\mathrm{Cu}^{\mathrm{II}}$ & - & 15 & 100 & 81 & {$[34]$} \\
\hline 6 & $\mathrm{Cu}(\mathrm{I})-\mathrm{MOF}$ & - & 14 & 80 & 90 & {$[35]$} \\
\hline 7 & IRMOF-3-Gl-Cu & $\mathrm{CHCl}_{3}$ & 6 & 40 & 90 & {$[36]$} \\
\hline 8 & $\mathrm{SiO}_{2}-\mathrm{NHC}-\mathrm{Cu}^{\mathrm{I}}$ & - & 24 & 25 & 94 & [37] \\
\hline 9 & $\mathrm{Cu}^{\mathrm{I}}$-Zeolite & - & 15 & 80 & 70 & {$[38]$} \\
\hline 10 & $\begin{array}{l}\mathrm{Fe}_{3} \mathrm{O}_{4} \mathrm{NPs} / \mathrm{GO}-\mathrm{CuO} \\
\mathrm{NPs}\end{array}$ & $\mathrm{EtOH}$ & 24 & 90 & 87 & {$[39]$} \\
\hline 11 & $\mathrm{Cu}$ NPs $/ \mathrm{TiO}_{2}$ & - & 7 & 70 & 91 & {$[32]$} \\
\hline 12 & $\mathrm{Cu}$ NPs & - & 10 & 110 & 88 & $\begin{array}{l}\text { This } \\
\text { work }\end{array}$ \\
\hline
\end{tabular}

${ }^{a}$ pip: 2-picolyliminomethyl)pyrrole anion; Go: graphene oxide; AAIL: amino acid ionic liquids; CMC: carboxymethylcellulose; NHC: $N$-heterocyclic carbenes.

solvents were used as received. All the chemicals were purchased from commercial sources and used as received unless stated otherwise. All reaction temperatures refer to bath temperatures. Column chromatography was carried out on silica gel (200 300 mesh). NMR spectra were recorded on a Bruker $400 \mathrm{MHz}$ spectrometer. The X-ray diffraction (XRD) patterns were recorded on a Germany Bruker $\mathrm{AX}$ in the range of $10^{\circ} \sim 89^{\circ}$. TEM images were carried out using a Philips CM10 transmission electron microscope. $\mathrm{Cu}$ NPs were synthesized according to our previous work. $^{[29]}$

\subsection{General procedure for the preparation of pro- pargylamine derivatives}

$\mathrm{Cu}$ NPs (10 mol\%), aldehyde (1 mmol), amine (1.2 $\mathrm{mmol})$ and alkyne $(1.5 \mathrm{mmol})$ were added to a $25 \mathrm{~mL}$ reaction tube, and the mixture was protected with argon and sealed. The reaction tube was placed in a frying pan at a certain temperature for a certain period of time, the progress of the reaction was monitored by thin layer chroma- tography (TLC), and the reaction time was recorded. After the reaction was stopped, the reaction tube was cooled to room temperature, $15 \mathrm{~mL}$ of ethyl acetate was added, the $\mathrm{Cu}$ salt was removed by filtration, and the solvent was concentrated on a rotary evaporator to obtain viscous yellow liquid. The residue was purified by flash column chromatography on silica gel (eluent: $V$ (petroleum ether) : $V($ ethyl acetate $)=10: 1)$ to give the corresponding product. The obtained product was dried in a vacuum oven at $60{ }^{\circ} \mathrm{C}$ for $3 \mathrm{~h}$ and then weighed.

4-(1,3-Diphenylprop-2-yn-1-yl)morpholine (4a): $:^{[17]} \quad{ }^{1} \mathrm{H}$ NMR (400 MHz, $\left.\mathrm{CDCl}_{3}\right) \delta: 7.68$ (d, $\left.J=7.4 \mathrm{~Hz}, 2 \mathrm{H}\right), 7.55$ (dd, $J=5.9,3.0 \mathrm{~Hz}, 2 \mathrm{H}), 7.36(\mathrm{dd}, J=15.0,6.1 \mathrm{~Hz}, 6 \mathrm{H})$, $4.83(\mathrm{~s}, 1 \mathrm{H}), 3.81 \sim 3.72(\mathrm{~m}, 4 \mathrm{H}), 2.67(\mathrm{t}, J=4.7 \mathrm{~Hz}, 4 \mathrm{H})$.

1-(1,3-Diphenylprop-2-yn-1-yl)-4-methylpiperidine (4b):: ${ }^{[28]}{ }^{1} \mathrm{H}$ NMR $\left(400 \mathrm{MHz}, \mathrm{CDCl}_{3}\right) \delta: 7.78(\mathrm{~d}, J=7.5 \mathrm{~Hz}$, 2H), 7.55 (dd, $J=5.9,3.1 \mathrm{~Hz}, 2 \mathrm{H}), 7.36(\mathrm{dd}, J=15.0,6.1$ $\mathrm{Hz}, 6 \mathrm{H}), 4.93$ (s, 1H), $2.16 \sim 2.84(\mathrm{~m}, 4 \mathrm{H}), 1.69 \sim 1.32(\mathrm{~m}$, $4 \mathrm{H}), 1.21 \sim 1.07(\mathrm{~m}, 1 \mathrm{H}), 0.83(\mathrm{~d}, J=7.1 \mathrm{~Hz}, 3 \mathrm{H})$.

1-(1,3-Diphenyl-2-propynyl)pyrrolidine $\quad(4 \mathbf{c})::^{[17]} \quad{ }^{1} \mathrm{H}$ NMR $\left(400 \mathrm{MHz}, \mathrm{CDCl}_{3}\right) \delta: 7.67 \sim 7.63(\mathrm{~m}, 2 \mathrm{H}), 7.53 \sim$ $7.50(\mathrm{~m}, 2 \mathrm{H}), 7.43 \sim 7.31(\mathrm{~m}, 6 \mathrm{H}), 5.24(\mathrm{~s}, 1 \mathrm{H}), 2.83 \sim$ $2.77(\mathrm{~m}, 4 \mathrm{H}), 1.74(\mathrm{t}, J=8.0 \mathrm{~Hz}, 4 \mathrm{H})$.

4-(3-Phenylprop-2-yn-1-yl)morpholine $\quad(4 d)::^{[34]} \quad{ }^{1} \mathrm{H}$ NMR (400 MHz, $\mathrm{CDCl}_{3}$ ) $\delta: 7.36$ (ddd, $J=6.7,3.4,1.6 \mathrm{~Hz}$, $2 \mathrm{H}), 7.17(\mathrm{dt}, J=5.0,1.6 \mathrm{~Hz}, 3 \mathrm{H}), 3.66 \sim 3.68(\mathrm{~m}, 4 \mathrm{H})$, $3.41(\mathrm{~s}, 2 \mathrm{H}), 2.53 \sim 2.55(\mathrm{~m}, 4 \mathrm{H})$.

4-Methyl-1-(3-phenylprop-2-yn-1-yl)piperidine (4e): $:^{[28]}$ ${ }^{1} \mathrm{H}$ NMR (400 MHz, $\mathrm{CDCl}_{3}$ ) $\delta: 7.34$ (ddd, $J=6.7,3.4,1.6$ $\mathrm{Hz}, 2 \mathrm{H}), 7.17$ (dt, $J=5.0,1.6 \mathrm{~Hz}, 3 \mathrm{H}), 3.37$ (s, 2H), 2.85 $2.26(\mathrm{~m}, 4 \mathrm{H}), 1.67 \sim 1.31(\mathrm{~m}, 4 \mathrm{H}), 1.31 \sim 1.17(\mathrm{~m}, 1 \mathrm{H})$, $0.82(\mathrm{~d}, J=7.1 \mathrm{~Hz}, 3 \mathrm{H})$.

1-(3-Phenylprop-2-yn-1-yl)pyrrolidine (4f): ${ }^{[17]}{ }^{1} \mathrm{H}$ NMR $\left(400 \mathrm{MHz}, \mathrm{CDCl}_{3}\right) \delta: 7.35 \sim 7.32(\mathrm{~m}, 2 \mathrm{H}), 7.20 \sim 7.18(\mathrm{~m}$, $3 \mathrm{H}), 3.54(\mathrm{~s}, 2 \mathrm{H}), 2.61(\mathrm{t}, J=6.8 \mathrm{~Hz}, 4 \mathrm{H}), 1.76 \sim 1.72(\mathrm{~m}$, $4 \mathrm{H})$.

4-(3-Phenyl-1-(thiophen-2-yl)prop-2-yn-1-yl)morpholine $(\mathbf{4 g}):{ }^{[41]}{ }^{1} \mathrm{H}$ NMR $\left(400 \mathrm{MHz}, \mathrm{CDCl}_{3}\right) \delta: 7.55 \sim 7.53(\mathrm{~m}$, $2 \mathrm{H}), 7.38 \sim 7.37(\mathrm{~m}, 3 \mathrm{H}), 7.10(\mathrm{~d}, J=4.8 \mathrm{~Hz}, 1 \mathrm{H}), 7.31 \sim$ $7.27(\mathrm{~m}, 1 \mathrm{H}), 7.01(\mathrm{~d}, J=7.1 \mathrm{~Hz}, 1 \mathrm{H}), 5.03(\mathrm{~s}, 1 \mathrm{H}), 3.83 \sim$ 
$3.77(\mathrm{~m}, 4 \mathrm{H}), 2.67$ (t, $J=6.8 \mathrm{~Hz}, 4 \mathrm{H})$.

1-(3-Phenyl-1-(thiophen-2-yl)prop-2-yn-1-yl)pyrrolidine (4i): ${ }^{[41]}{ }^{1} \mathrm{H}$ NMR $\left(400 \mathrm{MHz}, \mathrm{CDCl}_{3}\right) \delta: 7.56 \sim 7.42(\mathrm{~m}$, 2H), $7.38 \sim 7.35(\mathrm{~m}, 3 \mathrm{H}), 7.10(\mathrm{~d}, J=4.8 \mathrm{~Hz}, 1 \mathrm{H}), 7.27 \sim$ $7.21(\mathrm{~m}, 1 \mathrm{H}), 7.01(\mathrm{dd}, J=8.4,6.3 \mathrm{~Hz}, 1 \mathrm{H}), 4.88(\mathrm{~s}, 1 \mathrm{H})$, $3.69 \sim 3.61(\mathrm{~m}, 4 \mathrm{H}), 2.62 \sim 2.52(\mathrm{~m}, 4 \mathrm{H})$.

4-(1-(2-Chlorophenyl)-3-phenylprop-2-yn-1-yl)morpholine $(\mathbf{4 j}):{ }^{[34]}{ }^{1} \mathrm{H}$ NMR $\left(400 \mathrm{MHz}, \mathrm{CDCl}_{3}\right) \delta: 7.67 \sim 7.66(\mathrm{~m}$, $1 \mathrm{H}), 7.41$ (ddt, $J=5.6,3.0,1.6 \mathrm{~Hz}, 2 \mathrm{H}), 7.31 \sim 7.29(\mathrm{~m}$, $1 \mathrm{H}), 7.23$ (ddt, $J=5.9,4.2,2.3 \mathrm{~Hz}, 3 \mathrm{H}), 7.20 \sim 7.13(\mathrm{~m}$, 2H), 5.03 (s, 1H), 3.64 (q, $J=4.6 \mathrm{~Hz}, 4 \mathrm{H}), 2.59$ (t, $J=4.7$ $\mathrm{Hz}, 4 \mathrm{H})$.

1-(1-(2-Chlorophenyl)-3-phenylprop-2-yn-1-yl)-4-methylpiperidine (4k): ${ }^{[28]}{ }^{1} \mathrm{H}$ NMR $\left(400 \mathrm{MHz}, \mathrm{CDCl}_{3}\right) \quad \delta$ : $7.81 \sim 7.79(\mathrm{~m}, 1 \mathrm{H}), 7.55 \sim 7.44(\mathrm{~m}, 5 \mathrm{H}), 7.35 \sim 7.25(\mathrm{~m}$, $3 \mathrm{H}), 5.18(\mathrm{~s}, 1 \mathrm{H}), 2.89 \sim 2.36(\mathrm{~m}, 4 \mathrm{H}), 1.67 \sim 1.36(\mathrm{~m}$, $4 \mathrm{H}), 1.20 \sim 1.07(\mathrm{~m}, 1 \mathrm{H}), 0.95(\mathrm{~d}, J=7.1 \mathrm{~Hz}, 3 \mathrm{H})$.

1-(1-(2-Chlorophenyl)-3-phenylprop-2-yn-1-yl)pyrrolidine (4l): ${ }^{[40]}{ }^{1} \mathrm{H}$ NMR $\left(400 \mathrm{MHz}, \mathrm{CDCl}_{3}\right) \delta: 7.67 \sim 7.66$ (m, 1H), 7.45 (ddt, $J=5.6,3.0,1.6 \mathrm{~Hz}, 2 \mathrm{H}), 7.32 \sim 7.29$ (m, 1H), 7.24 (ddt, $J=5.9,4.2,2.3 \mathrm{~Hz}, 3 \mathrm{H}), 7.20 \sim 7.13$ $(\mathrm{m}, 2 \mathrm{H}), 5.29(\mathrm{~s}, 1 \mathrm{H}), 3.69 \sim 3.61(\mathrm{~m}, 4 \mathrm{H}), 2.62 \sim 2.52(\mathrm{~m}$, $4 \mathrm{H})$.

4-(1-(3,4-Dimethoxyphenyl)-3-phenylprop-2-yn-1-yl)morpholine (4m): ${ }^{[34]}{ }^{1} \mathrm{H}$ NMR (400 $\left.\mathrm{MHz}, \mathrm{CDCl}_{3}\right) \delta$ : $7.51 \sim 7.49(\mathrm{~m}, 2 \mathrm{H}), 7.45 \sim 7.40(\mathrm{~m}, 3 \mathrm{H}), 7.30 \sim 7.22(\mathrm{~m}$, $2 \mathrm{H}), 6.94 \sim 6.83(\mathrm{~m}, 1 \mathrm{H}), 4.72(\mathrm{~s}, 1 \mathrm{H}), 3.94 \sim 3.84(\mathrm{~m}$, $6 \mathrm{H}), 3.76(\mathrm{td}, J=5.2,2.4 \mathrm{~Hz}, 4 \mathrm{H}), 2.67 \sim 2.58(\mathrm{~m}, 4 \mathrm{H})$.

1-(1-(3,4-Dimethoxyphenyl)-3-phenylprop-2-yn-1-yl)-4methylpiperidine (4n): ${ }^{[28]}{ }^{1} \mathrm{H}$ NMR (400 $\left.\mathrm{MHz}, \mathrm{CDCl}_{3}\right) \delta$ : $7.53 \sim 7.49(\mathrm{~m}, 2 \mathrm{H}), 7.45 \sim 7.39(\mathrm{~m}, 3 \mathrm{H}), 7.30 \sim 7.22(\mathrm{~m}$, $2 \mathrm{H}), 6.95 \sim 6.84(\mathrm{~m}, 1 \mathrm{H}), 4.77(\mathrm{~s}, 1 \mathrm{H}), 3.96 \sim 3.88(\mathrm{~m}$, $6 \mathrm{H}), 2.94 \sim 2.36(\mathrm{~m}, 4 \mathrm{H}), 1.67 \sim 1.31(\mathrm{~m}, 4 \mathrm{H}), 1.20 \sim 1.09$ (m, 1H), $0.93(\mathrm{~d}, J=7.1 \mathrm{~Hz}, 3 \mathrm{H})$.

1-(1-(3,4-Dimethoxyphenyl)-3-phenylprop-2-yn-1-yl)pyrrolidine (4o): ${ }^{[34]}{ }^{1} \mathrm{H}$ NMR (400 $\left.\mathrm{MHz}, \mathrm{CDCl}_{3}\right) \delta: 7.54 \sim$ $7.49(\mathrm{~m}, 2 \mathrm{H}), 7.46 \sim 7.40(\mathrm{~m}, 3 \mathrm{H}), 7.30 \sim 7.24(\mathrm{~m}, 2 \mathrm{H})$, $6.85 \sim 6.83(\mathrm{~m}, 1 \mathrm{H}), 4.79(\mathrm{~s}, 1 \mathrm{H}), 3.91 \sim 3.87(\mathrm{~m}, 6 \mathrm{H})$, $3.69 \sim 3.61(\mathrm{~m}, 4 \mathrm{H}), 2.62 \sim 2.52(\mathrm{~m}, 4 \mathrm{H})$.

4-(1-(4-Nitrophenyl)-3-phenylprop-2-yn-1-yl)morpholine $(4 r):{ }^{[33]}{ }^{1} \mathrm{H}$ NMR $\left(400 \mathrm{MHz}, \mathrm{CDCl}_{3}\right) \delta: 8.21 \sim 8.17(\mathrm{~m}$, $2 \mathrm{H}), 7.87 \sim 7.85(\mathrm{~m}, 2 \mathrm{H}), 7.54 \sim 7.53(\mathrm{~m}, 2 \mathrm{H}), 7.36 \sim 7.34$ $(\mathrm{m}, 3 \mathrm{H}), 4.88(\mathrm{~s}, 1 \mathrm{H}), 3.71 \sim 3.64(\mathrm{~m}, 4 \mathrm{H}), 2.66 \sim 2.61(\mathrm{~m}$, $4 \mathrm{H})$.

4-(3-Phenyl-1-(4-(trifluoromethyl)phenyl)prop-2-yn-1yl)morpholine (4s): $:^{[39]}{ }^{1} \mathrm{H}$ NMR $\left(400 \mathrm{MHz}, \mathrm{CDCl}_{3}\right) \delta$ : $7.79 \sim 7.77(\mathrm{~m}, 2 \mathrm{H}), 7.63 \sim 7.51(\mathrm{~m}, 3 \mathrm{H}), 7.35 \sim 7.24(\mathrm{~m}$, $4 \mathrm{H}), 4.83(\mathrm{~s}, 1 \mathrm{H}), 3.81 \sim 3.72(\mathrm{~m}, 4 \mathrm{H}), 2.67(\mathrm{t}, J=4.7 \mathrm{~Hz}$, $4 \mathrm{H})$.

4-(1-Phenylhept-1-yn-3-yl)morpholine (4t): $:^{[34]}{ }^{1} \mathrm{H}$ NMR $\left(400 \mathrm{MHz}, \mathrm{CDCl}_{3}\right) \delta: 7.44 \sim 7.42(\mathrm{~m}, 2 \mathrm{H}), 7.28(\mathrm{~d}, J=2.6$ $\mathrm{Hz}, 3 \mathrm{H}), 3.79 \sim 3.70(\mathrm{~m}, 4 \mathrm{H}), 3.51(\mathrm{t}, J=7.4 \mathrm{~Hz}, 1 \mathrm{H}), 2.72$ (dddd, $J=53.4,11.4,6.0,3.6 \mathrm{~Hz}, 4 \mathrm{H}), 1.73 \sim 1.64(\mathrm{~m}$, $2 \mathrm{H}), 1.46 \sim 1.30(\mathrm{~m}, 4 \mathrm{H}), 0.95(\mathrm{~d}, J=7.1 \mathrm{~Hz}, 3 \mathrm{H})$.

4-(1-Phenylhex-1-yn-3-yl)morpholine (4u): ${ }^{[34]}{ }^{1} \mathrm{H}$ NMR $\left(400 \mathrm{MHz}, \mathrm{CDCl}_{3}\right) \delta: 7.43 \sim 7.42(\mathrm{~m}, 2 \mathrm{H}), 7.28 \sim 7.27(\mathrm{~m}$, $3 \mathrm{H}), 3.79 \sim 3.70(\mathrm{~m}, 4 \mathrm{H}), 3.45(\mathrm{dd}, J=8.4,6.3 \mathrm{~Hz}, 1 \mathrm{H})$,
2.56 (dddd, $J=53.0,11.3,6.0,3.7 \mathrm{~Hz}, 4 \mathrm{H}), 1.72 \sim 1.44$ $(\mathrm{m}, 4 \mathrm{H}), 0.97(\mathrm{t}, J=7.2 \mathrm{~Hz}, 3 \mathrm{H})$.

Supporting Information Nuclear magnetic resonance spectrum of some propargylamine compounds. The Supporting Information is available free of charge via the Internet at http://sioc-journal.cn.

\section{References}

[1] Loni, M.; Yazdani, H.; Bazgir, A. Catal. Lett. 2018, 148, 3467.

[2] Wan, J. P.; Gan, L.; Liu, Y. Y. Org. Biomol. Chem. 2017, 15, 9031.

[3] (a) Chen, H. B.; Zhao, Y.; Liao, Y. RSC Adv. 2015, 5, 37737. (b) Cai, L. Z.; Huang, Z.; Yang, L. Q.; Xie, X. M.; Tao, X. C. Chin. J. Org. Chem. 2018, 38, 3326 (in Chinese).

(蔡良珍，黄振，杨立群，谢小敏，陶晓春，有机化学， 2018，38， 3326.)

(c) Liang, T.-T.; Jiang, L.; Gan, M.-M.; Su, X.; Li, Z. N. Chin. J. Org. Chem. 2017, 37, 3096 (in Chinese).

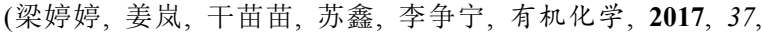
3096.)

[4] Bolea, I.; Gella, A.; Unzeta, M. J. Neural Transm. 2013, 120, 893.

[5] Peshkov, V. A.; Pereshivko, O. P.; Van der Eycken, E. V. Chem. Soc. Rev. 2012, 41, 3790.

[6] Zani, L.; Bolm, C. Chem. Commun. 2006, 38, 4263.

[7] Zhang, P. Y.; Song, T.; Wang, T. T.; Zeng, H. P. Appl. Catal., B 2017, 206, 328.

[8] Kumari, S.; Shekhar, A.; Pathak, D. D. RSC Adv. 2016, 6, 15340.

[9] Varyani, M.; Khatri, P. K.; Jain, S. L. Catal. Commun. 2016, 77, 113.

[10] Sadjadi, S.; Heravi, M. M.; Malmir, M.; Noritajer, F. Mater. Chem. Phys. 2019, 223, 380.

[11] Zhou, Y. P.; He, T. T.; Wang, Z. Y. ARKIVOC 2008, 13, 80.

[12] Cao, J.; Xu, G.; Li, P. Y.; Tao, M. L.; Zhang, W. ACS Sustainable Chem. Eng. 2017, 5, 3438.

[13] Su, Y. J.; Lu, M.; Dong, B. L.; Chen, H.; Shi, X. D. Adv. Synth. Catal. 2014, 356, 692

[14] Yadav, J. S.; Reddy, B. V. S.; Gopal, A. V. H.; Patil, K. S. Tetrahedron Lett. 2009, 50, 3493.

[15] Zhang, Y. C.; Li, P. H.; Wang, M.; Wang, L. J. Org. Chem. 2009, $74,4364$.

[16] Teimouri, A.; Chermahini, A. N.; Narimani, M. B. Korean Chem. Soc. 2012, 33, 1556

[17] Shi, X. L.; Sun, B. Y.; Chen, Y. J.; Hua, Q. Q.; Li, P. Y. Y.; Meng, L.; Duan, P. G. J. Catal. 2019, 372, 321.

[18] Gajengi, A. L.; Sasaki, T.; Bhanage, B. M. Catal. Commun. 2015, 72,174 .

[19] Zeng, T. Q.; Chen, W. W.; Cirtiu, C. M.; Moores, A.; Song, G. H.; Li, C. J. Green Chem. 2010, 12, 570.

[20] Huo, X.; Liu, J. B. Wang, D.; Zhang, H. L.; Yang, Z. Y.; She, X. G.; Xia, P. X. J. Mater. Chem. A 2013, 1, 651.

[21] Manikandan, R.; Anitha, P.; Viswanathamurthi, P.; Malecki, J. G. Polyhedron 2016, 119, 300.

[22] Srinivas, V.; Koketsu, M. Tetrahedron 2013, 69, 8025.

[23] Huang, J. L.; Gray, D. G.; Li, C. J. Beilstein J. Org. Chem. 2013, 9, 1388.

[24] Bosica, G.; Abdilla, R.; J. Mol. Catal. A: Chem. 2017, 426, 542.

[25] Choi, Y. J.; Jang, H. Y. Eur. J. Org. Chem. 2016, $2016,3047$.

[26] Gulati, U.; Rajesh, U. C.; Rawat, D. S. Tetrahedron Lett. 2016, 57, 4468.

[27] Turberg, M.; Ardila-Fierro, K. J.; Bolm, C.; Hernández, J. G. Angew. Chem., Int. Ed. 2018, 57, 10718.

[28] Mirabedini, M.; Motamedi, E.; Kassaee, M. Z. Chin. Chem. Lett. 2015, 26, 1085.

[29] Duan, Z. Y.; Ma, G. L.; Zhang. W. J. Bull. Korean Chem. Soc. 2012, 33, 4003.

[30] Patil, S. A.; Ryu, C. H.; Kim, H. S. Int. J. Precis. Eng. Man- 
uf.-Green Tech. 2018, 5, 239.

[31] Tajbaksh, M.; Farhang, M.; Mardani, H. R.; Hosseinzadeh, R. Chin. J. Catal. 2013, 34, 2217.

[32] Albaladejo, M. J.; Alonso, F.; Moglie, Y.; Yus, M. Eur. J. Org. Chem. 2012, 2012, 3093.

[33] Agrahari, B.; Layek, S.; Ganguly, R.; Pathak, D. D. New J. Chem. 2018, 42, 13754

[34] Liu, X. P.; Lin, B. J.; Zhang, Z.; Lei, H.; Li, Y. Q. RSC Adv. 2016, 6, 94399.

[35] Li, P.; Regati, S.; Huang, H. C.; Arman, H. D.; Chen, B. L. Zhao, J.
C. G. Chin. Chem. Lett. 2015, 26, 6.

[36] Yang, J.; Li, P.; Wang, L. Catal. Commun. 2012, 27, 58.

[37] Wang, M.; Li, P.; Wang, L. Eur. J. Org. Chem. 2008, 2008, 2255.

[38] Patil, M. K.; Keller, M.; Reddy, B. M.; Pale, P.; Sommer, J. Eur. J. Org. Chem. 2008, 4440.

[39] Zarei, Z.; Akhlaghinia, B. RSC Adv. 2016, 6, 106473.

[40] Varyani, M.; Khatri, P. K.; Jain, S. L. Catal. Commun. 2016, 77, 113.

[41] Gholinejad, M.; Karimi, B.; Aminianfar, A.; Khorasani, Mojtaba. ChemPlusChem 2015, 80, 1573.

(Li, L.; Fan, Y.) 